\title{
Composition of Ions and Trace Metals in Rainwater in Bandung City, Indonesia
}

\author{
Nia Yuniarti Hasan ${ }^{1}$, Driejana ${ }^{2 *}$, Aminudin Sulaeman ${ }^{3}$ \\ ${ }^{1}$ Graduate Program of Environmental Engineering, Institut Teknologi Bandung, Jl. Ganesa 10, Bandung 40132. \\ ${ }^{2}$ Air and Waste Management Research Group, Faculty of Civil and Environmental Engineering, Institut Teknologi \\ Bandung, Jl. Ganesa 10, Bandung 40132 \\ ${ }^{3}$ Analytical Chemistry Research Group, Faculty of Mathematics and Sciences, Institut Teknologi Bandung,Jl. Ganesa \\ 10, Bandung 40132. \\ *Corresponding author: driejana@tl.itb.ac.id
}

\begin{abstract}
The basin shape of Bandung limits dispersion and transport of air pollutants. This topographical characteristic causes air pollutants to be trapped and accumulated within the basin, where urban areas were located. In the issue of of sustainable city, rainwater could be potential sources of fresh water. However, air pollution in urban area might alter the natural rainwater composition. Characterization of rainwater was conducted by collecting rainwater bulk samples at 4 (four) sites located in a transect from high elevation to the lowest at the base of the Bandung basin. Identification of trace metals, cations and anions were performed in rainwater collected in Bandung City during rainy seasons in February to March 2016. Acidity (pH), conductivity, anions and cations $\left(\mathrm{SO}_{4}{ }^{2-}, \mathrm{NO}_{3}{ }^{-}, \mathrm{Cl}^{-}, \mathrm{Ca}^{2+}, \mathrm{Mg}^{2+}, \mathrm{Na}^{+}, \mathrm{K}^{+}\right.$and $\left.\mathrm{NH}_{4}{ }^{+}\right)$and trace metals of $\mathrm{Ag}, \mathrm{Al}, \mathrm{As}$, $\mathrm{Ba}, \mathrm{Cd}, \mathrm{Co}, \mathrm{Cr}, \mathrm{Cu}, \mathrm{Fe}, \mathrm{Ni}, \mathrm{Pb}, \mathrm{Sb}, \mathrm{Se}, \mathrm{Sn}, \mathrm{Sr}$ and $\mathrm{Zn}$ were analysed. During the sampling period, the rainfall rate ranged between $19.02 \mathrm{~mm} /$ week to $130.48 \mathrm{~mm} /$ week. The results show that rainwater $\mathrm{pH}$ were $4.10-5.95$. The dominant chemical composition of rainwater were sulfat $(37 \%-39 \%)$ and ammonium $(17 \%-26 \%)$, followed by nitrate. The trace metals analyses indicated that lead $(\mathrm{Pb})$ had the highest concentration (mean = 76.68 $\mu \mathrm{g} / \mathrm{L}$ ). The concentration of the trace metals decreased in order of $\mathrm{Pb}, \mathrm{Fe}, \mathrm{Zn}, \mathrm{Al}, \mathrm{Se}, \mathrm{Cu}, \mathrm{As}, \mathrm{Ba}, \mathrm{Co}, \mathrm{Sr}$, $\mathrm{Ni}, \mathrm{Cd}, \mathrm{Cr}$, Sn and $\mathrm{Sb}$. Lead is a toxic compound, resulting from human activities, such as fossil fuel burning, mining and manufacturing. The initial analysis of rainwater composition including heavy metals suggested that rainwater contain various and potential harmful substances, including heavy metals. These findings are particularly important and should be taken into consideration in the context of rainwater as a water sources in urban area, e,g. rainwater harvesting for the domestic purposes and urban farming.
\end{abstract}

Keywords — rainwater analysis, rainwater quality, rainwater harvesting, urban air pollution, heavy metal, sustainable city

\section{INTRODUCTION}

$\mathrm{R}$ ainwater is a free source of nearly pure water. The natural chemical composition of the atmosphere is affected by human activities. Pollutant emissions are mainly produced by chemical industrial processes, fuel combustion from automobiles, and anthropogenic activities. Most of the pollutants are transported by winds from the industrial localities and national highways.

Anthropogenic emissions result in the presence of polluting compounds in the environment. In high populated cities, gases and particulate matter were dispersed and accumulated in the atmosphere. Although their natural concentrations rarely reach harmful levels, they can be dangerous to human health and to the environment at high concentrations [1].

Rainwater chemistry and trace metals has been studied in urban and rural areas $[2,3,4,5]$. Study of heavy metals in rainwater has increased in the last decades because of their adverse environmental and human health effects. Rainwater is an important means of scavenging pollutants from the atmosphere, which can occur either in the gaseous or in the particulate phase. The composition of rainwater actually reflects the composition of the atmosphere through which it falls [2].

Anthropogenic sources have substantially increased heavy metal concentrations in atmospheric deposition. If the concentrations are too high, many of the heavy metals can harm human health through the consumption of drinking water and/ or aquatic organisms [6].

Rainwater composition including heavy metals suggested that rainwater contain various and potential harmful substance for human health. These findings are particularly important and should be taken into consideration in the context of rainwater as a water sources in urban area, e,g. rainwater harvesting for the domestic purposes and urban farming.

Study of urban farming such as green (vegetated) roofs in Singapore showed that green roof reasonably effective 
to adsorb various metals $(\mathrm{Na}, \mathrm{K}, \mathrm{Ca}, \mathrm{Mg}, \mathrm{Al}, \mathrm{Fe}, \mathrm{Cu}, \mathrm{Cd}$, $\mathrm{Pb}, \mathrm{Zn}, \mathrm{Mn}, \mathrm{Cr}, \mathrm{Ni}, \mathrm{Li}$ and $\mathrm{Co})$, inorganic anions $\left(\mathrm{NO}_{2}{ }^{-}\right.$, $\mathrm{SO}_{4}{ }^{2-}, \mathrm{Cl}^{-}, \mathrm{F}^{-}$and $\left.\mathrm{Br}^{-}\right)$and cation $\left(\mathrm{NH}_{4}^{+}\right)$except $\mathrm{NO}_{3}{ }^{-}$and $\mathrm{PO}_{4}^{-}$. However, the concentration of these chemical components in the roof runoff strongly depends on the nature of substrates used in the green roof and the volume of rain [7].

The high variability in the rainwater chemical composition due to the varying topography of the region indicates that ion concentrations in mountainous areas have higher concentrations than other lower regions as a result of the orographic enhancement process, whereas in the lower regions it is caused by local sources $[8,9,10,11]$.

The factor of excessive concentration of main ions in rainwater in Great Dunn Fell UK with an altitude of 847 meters between 2 - 3.9 compared to areas with a height of 250 meter above sea level [8]. Orographic enhancement is caused by the effects of seeder-feeder where rainfall is increasing in the highlands of clouds at high (seeder) in high hills and mountains [12].

The basin of Bandung limits dispersion and transport of air pollutants. This topographical causes pollutants to be trapped and accumulated within the basin, where urban area is located. In this study, the concentrations of ions and trace metals were determined. Concentration of major ions $\left(\mathrm{SO}_{4}^{2-}, \mathrm{NO}_{3}^{-}, \mathrm{Cl}^{-}, \mathrm{Ca}^{+}, \mathrm{Mg}^{+}, \mathrm{Na}^{+}, \mathrm{K}^{+}\right.$and $\mathrm{NH}_{4}^{+}$) and trace metals (Al, As, Ba, Cd, Co, Cr, Cu, Fe, $\mathrm{Ni}, \mathrm{Pb}, \mathrm{Sb}, \mathrm{Se}, \mathrm{Sn}, \mathrm{Sr}$ and $\mathrm{Zn}$ ) were analysed. Data of ions and trace metals in rainwater are used for further research studies in wet deposition in Bandung City.

\section{METHOD}

\subsection{Sampling Site}

Bandung is located in West Java, Indonesia. It is the capital City of West Java Province. Its geographical location is 107032 '38.91" $\mathrm{E}$ and 6055 "19.94" $\mathrm{S}$, while its altitude is between $675 \mathrm{~m}$ and $1.050 \mathrm{~m}$ above the sea level. Bandung atmospheric condition can be described as wet and humid. The average temperature is $23.4^{\circ} \mathrm{C}$, while the monthly rainfall range $0.6-418.7 \mathrm{~mm}$ in 2014 .

Bandung and its surrounding mountains was a great basin. Four sampling site were selected for rainwater collection, covering the basin transect (1) Buah Batu (642 m asl), (2) Sumur Bandung (742 m asl), (3) Coblong (803 m asl) and (4) Lembang (1272 m asl).

\subsection{Sample Collection}

Weekly rainwater samples were collected from February to March 2016. Rainwater samples were collected using a 120-mm diameter polyethylene funnel equipped with a removable 1-mm mesh filter plug.

The funnel is positioned on the top of a $1000 \mathrm{~mL}$ polyethylene bottle for sample storage inside a stainless steel cylinder canister [10].
Samples were collected every Wednesday following the same route to allow samples at approximately the same time. The collector bottle and funnel was replaced with a clean one and was rinsed with deionized water [10, 13].

\subsection{Sample Analysis}

After the rainwater samples were collected, the volume of samples ware measured. The $\mathrm{pH}$ and conductivity determined using Sartorius Professional Meter PP-20 and Agilent Technologies 3200 C Conductivity Meter.

Samples were then placed in the $100 \mathrm{~mL}$ polyethylene bottles, each for ion analysis and trace metals analysis and stored in the dark at $4^{\circ} \mathrm{C}$ until the chemical analysis $[10,14,15]$.

Anion and cation analysis measured using ion chromatograph DIONEX ICS 500 DP, concentrations were calculated by integrating the samples peaks and comparing with calibration curves using Thermo Scientific Dionex Chromeleon Chromatography Data System.

Trace metals analysis measured using inductively couple plasma ICP Agilent 700 series with ICP Expert II software $[14,15]$.

\subsection{Quality Assurance}

Ion balance (IB) is an effective tool for reviewing the ionic balance for each sample analysed. The principle of electro neutrality in precipitation requires that the total anion equals the total cation ( in equivalents concentration/normality). According to this principle, ion balance in a precipitation sample should be checked by the method described below [14] :

$$
I B=(C-A) /(C+A) \times 100 \%
$$

where $\mathrm{C}$ and $\mathrm{A}$ represents anion and cation equivalents $\left(\mu\right.$ eq $\left.\mathrm{L}^{-1}\right)$, respectively.

It is suggested that the difference between ions were IB \pm $8 \%$ if sum of ions $>100 \mu \mathrm{eq} / \mathrm{L}, \mathrm{IB} \pm 15 \%$ if sum of ions $50-100 \mu \mathrm{eq} / \mathrm{L}$ and IB $\pm 30 \%$ if sum of ions $<50 \mu \mathrm{eq} / \mathrm{L}$ [14].

\subsection{Precipitation-weight Mean Concentration (PWM)}

Precipitation-weight concentration mean (PWM) is given by the following equation [10]:

$$
C_{w \cdot j}=\sum C_{j . k} . P k / \sum P k
$$

Where $C_{w . j}$ is precipitation weight concentration for ion $\mathrm{j}$ $(\mu \mathrm{eq} / \mathrm{L}), \mathrm{C}_{\mathrm{j} . \mathrm{k}}$ is ion $\mathrm{j}$ concentration in precipitation of time $\mathrm{k}(\mu \mathrm{eq} / \mathrm{L})$ and $\mathrm{Pk}$ is precipitation amount of time $\mathrm{k}$ ( $\mathrm{mm} /$ time). The results are presented in Table 1 and 2. 
Regional Conference in Civil Engineering (RCCE)

The Third International Conference on Civil Engineering Research (ICCER)

August $1^{\text {st }}-2^{\text {nd }}$ 2017, Surabaya - Indonesia

Tabel 1 Ions composition of rainwater in Bandung City ( $\mu$ eq/L except $\mathrm{pH}$ )

\begin{tabular}{|c|c|c|c|c|c|c|c|c|c|c|}
\hline Sampling Point & Parameter & $\mathrm{SO}_{4}{ }^{2-}$ & $\mathrm{NO}_{3}^{-}$ & $\mathrm{Cl}^{-}$ & $\mathrm{Ca}^{2+}$ & $\mathrm{Mg}^{2+}$ & $\mathrm{Na}^{2+}$ & $\mathrm{K}^{+}$ & $\mathrm{NH}_{4}^{+}$ & $\mathrm{pH}$ \\
\hline \multirow{5}{*}{ Buah Batu } & Minimal & 49.82 & 16.22 & 4.34 & 20.25 & 3.37 & 1.74 & 0.87 & 12.97 & 4.69 \\
\hline & Maximal & 118.90 & 43.22 & 12.58 & 97.75 & 13.17 & 7.00 & 2.38 & 60.64 & 5.94 \\
\hline & & & & & & & & & & \\
\hline & Mean & 72.07 & 24.36 & 8.13 & 47.18 & 7.10 & 4.46 & 1.60 & 31.40 & 5.13 \\
\hline & PWM & 69.35 & 23.99 & 6.91 & 32.22 & 32.22 & 3.49 & 1.32 & 33.98 & 4.88 \\
\hline \multirow{5}{*}{ Sumur Bandung } & Minimal & 54.20 & 16.14 & 8.38 & 17.06 & 2.88 & 1.96 & 1.13 & 13.36 & 4.10 \\
\hline & Maximal & 129.98 & 47.65 & 28.35 & 76.76 & 8.89 & 9.18 & 48.36 & 58.37 & 5.87 \\
\hline & & & & & & & & & & \\
\hline & Mean & 80.75 & 28.54 & 15.42 & 50.86 & 7.20 & 5.69 & 14.14 & 32.97 & 4.92 \\
\hline & PWM & 79.81 & 27.89 & 11.97 & 36.20 & 5.49 & 4.11 & 12.57 & 35.76 & 4.40 \\
\hline \multirow{4}{*}{ Coblong } & Minimal & 31.46 & 14.22 & 5.19 & 7.65 & 1.56 & 1.13 & 0.97 & 6.82 & 4.37 \\
\hline & Maximal & 80.16 & 34.78 & 17.43 & 52.50 & 4.28 & 14.57 & 6.01 & 39.63 & 5.68 \\
\hline & Mop & 5270 & 20.96 & 934 & 2548 & 202 & 585 & 284 & 2672 & 478 \\
\hline & PWM & 53.71 & 20.57 & 8.46 & 17.74 & 2.44 & 4.62 & 2.21 & 30.24 & 4.53 \\
\hline \multirow{5}{*}{ Lembang } & Minimal & 19.20 & 11.01 & 0.00 & 9.02 & 1.98 & 2.35 & 0.23 & 15.85 & 4.47 \\
\hline & Maximal & 49.84 & 23.35 & 0.01 & 20.10 & 4.03 & 7.09 & 6.01 & 39.02 & 5.02 \\
\hline & & & & & & & & & & \\
\hline & Mean & 37.07 & 18.13 & 0.01 & 13.33 & 2.88 & 3.74 & 2.34 & 26.37 & 4.60 \\
\hline & PWM & 41.91 & 19.64 & 0.01 & 14.16 & 3.04 & 3.27 & 1.97 & 30.21 & 4.48 \\
\hline
\end{tabular}

Table 2.

Mean concentration of trace metals in rainwater $(\mu \mathrm{g} / \mathrm{L})$

\begin{tabular}{|c|c|c|c|c|c|c|c|c|c|c|c|c|c|c|c|}
\hline Site & $\mathrm{Al}$ & As & $\mathrm{Ba}$ & $\mathrm{Cd}$ & $\mathrm{Co}$ & $\mathrm{Cr}$ & $\mathrm{Cu}$ & $\mathrm{Fe}$ & $\mathrm{Ni}$ & $\mathrm{Pb}$ & $\mathrm{Sb}$ & $\mathrm{Se}$ & Sn & $\mathrm{Sr}$ & $\mathrm{Zn}$ \\
\hline Buah Batu & 50.85 & 7.9 & 1.075 & 0.75 & 1.675 & 0.7 & 4.575 & 43.85 & 0 & 24.88 & 9.05 & 19.5 & 0.525 & 0.75 & 7.93 \\
\hline Sumur Bandung & 26.23 & 0.50 & 4.83 & 1.50 & 1.20 & 1.58 & 4.88 & 76.48 & 5.73 & 217.20 & 0.60 & 11.45 & 0.00 & 5.90 & 90.18 \\
\hline Coblong & 16.93 & 2.05 & 3.63 & 3.33 & 5.40 & 3.30 & 4.45 & 9.03 & 2.20 & 40.73 & 1.98 & 12.78 & 0.00 & 7.33 & 4.48 \\
\hline Lembang & 9.8 & 16.93 & 16.63 & 17.23 & 15.73 & 16.90 & 21.30 & 9.80 & 15.78 & 23.90 & 0.00 & 43.83 & 13.50 & 9.98 & 31.50 \\
\hline Mean & 25.95 & 6.85 & 6.54 & 5.70 & 6.00 & 5.62 & 8.80 & 34.79 & 5.93 & 76.68 & 2.91 & 21.89 & 3.51 & 5.99 & 33.52 \\
\hline
\end{tabular}




\section{RESULTS AND DISCUSSION}

The average rainfall of during the sampling period at 4 sampling sites was $63.40 \mathrm{~mm}$,. The maximum rainfall was $130.48 \mathrm{~mm}$, which occurred in Buah Batu, and minimum rainfall was $19.92 \mathrm{~mm}$, which occurred in Sumur Bandung.

The descriptive statistic result of $\mathrm{pH}$ and major ionic composition are presented in Table 1. The minimum and maximum concentrations of major ions composition in the individual rainwater sample and Precipitation Weight Mean (PWM) are shown in Table 1.

\subsection{Conductivity and Acidity}

The electric conductivity of rainwater samples ranged $7.33 \mu \mathrm{S} / \mathrm{cm}$ - $37.40 \mu \mathrm{S} / \mathrm{cm}$, with mean $17.79 \mu \mathrm{S} / \mathrm{cm}$. Conductivity in rainwater is affected by the presence of ions that carry negative and positive charges. The common conductivity range of precipitation is 5 to 1000 $\mu \mathrm{S} \mathrm{cm}^{-1}[15]$.

Overall, the $\mathrm{pH}$ of rainwater ranged from $4.10-5.87$. The PWM pH was 4.67 indicating slight acidity in rainwater samples. The acidity of rainwater depends on the relative contribution and neutralization of the main acidic and alkaline ions [16].

\subsection{Ion Balance}

Ion balance provides a useful tool to evaluate the completeness of the analysed ions. Even though most of the analysed samples falls within the acceptable ions differences $( \pm 8-15 \%)$ for ionic balance, all samples display cation excess.

\subsection{Composition of Ions}

The major component of rainwater in Buah Batu were $\mathrm{SO}_{4}{ }^{2-}$ (PWM of $\left.69.35 \mu \mathrm{eq} / \mathrm{L}\right)$ representing $39 \%$ and $\mathrm{NH}_{4}{ }^{+}$(PWM of $\left.33.98 \mu \mathrm{eq} / \mathrm{L}\right)$ representing $19 \%$ of all ions. The major component of rainwater in Sumur Bandung were $\mathrm{SO}_{4}{ }^{2-}$ (PWM of $79.71 \mu \mathrm{eq} / \mathrm{L}$ ) representing $37 \%$ and $\mathrm{Ca}^{+}$(PWM of $36.20 \mu \mathrm{eq} / \mathrm{L}$ ) representing $17 \%$ of all ions.

The major component of rainwater in Coblong were $\mathrm{SO}_{4}{ }^{2-}$ (PWM of $\left.53.71 \mu \mathrm{eq} / \mathrm{L}\right)$ representing $38 \%$ and $\mathrm{NH}_{4}{ }^{+}$(PWM of $30.24 \mu \mathrm{eq} / \mathrm{L}$ ) representing $22 \%$ of all ions. The major component of rainwater in Lembang were $\mathrm{SO}_{4}{ }^{2-}(\mathrm{PWM}$ of $41.91 \mu \mathrm{eq} / \mathrm{L})$ representing $37 \%$ and $\mathrm{NH}_{4}{ }^{+}(\mathrm{PWM}$ of $30.21 \mu \mathrm{eq} / \mathrm{L})$ representing $26 \%$ of all ions.

The acidic component $\left(\mathrm{SO}_{4}{ }^{2-}, \mathrm{NO}_{3}{ }^{-}\right.$and $\left.\mathrm{Cl}^{-}\right)$for all sampling site contribute about $54 \%-69 \%$ of the total ion compare to the alkaline component $\left(\mathrm{Ca}^{2+}, \mathrm{Mg}^{2+}, \mathrm{Na}^{+}\right.$, $\mathrm{K}^{+}$and $\mathrm{NH}_{4}^{+}$) of about $31 \%-46 \%$.

The high fuel consumption from urbanized and the rapid increase of vehicle growth resulted in the high emission of $\mathrm{SO}_{2}$ and $\mathrm{NO}_{\mathbf{x}}$, which were the precursors of the high concentration of acidic ions $\mathrm{SO}_{4}{ }^{2}-$ and $\mathrm{NO}_{3}{ }^{-}$in rainwater as also were found in Chengdu Southwest China [17].
$\mathrm{NH}_{4}{ }^{+}$primarily comes from fertilizers used in agriculture, biomass burning, livestock breeding and natural activities [15]. There are not many agricultural areas in the city of Bandung. It is suggested that ammonia is originated from decomposition process of waste and wastewater mix in open channel of the cities. However, this is still need further investigation.

\subsection{Identification of Trace Metals}

Identification of trace metals in rainwater sample are representing in Table 2. Trace metals are $\mathrm{Al}, \mathrm{As}, \mathrm{Ba}, \mathrm{Cd}$, $\mathrm{Co}, \mathrm{Cr}, \mathrm{Cu}, \mathrm{Fe}, \mathrm{Ni}, \mathrm{Pb}, \mathrm{Sb}, \mathrm{Se}, \mathrm{Sn}, \mathrm{Sr}$ and $\mathrm{Zn}$ with mean range concentration $2.91 \mu \mathrm{g} / \mathrm{L}(\mathrm{Sb})-76.68(\mathrm{~Pb})$.

Lead $(\mathrm{Pb})$ had the highest concentration (mean $=76.68$ $\mu \mathrm{g} / \mathrm{L})$. The concentration of the trace metals $(\mu \mathrm{g} / \mathrm{L})$ decreased in order of $\mathrm{Fe}$ (34.79), $\mathrm{Zn}$ (33.52), $\mathrm{Al}$ (25.95), $\mathrm{Se}$ (21.89), Cu (8.80), As (6.85), Ba (6.52), Co (6.00), Sr (5.99), Ni (5.95), Cd (5.70), Cr (5.62), Sn (3.51) and Sb (2.91) $\mu \mathrm{g} / \mathrm{L}$.

The concentration of trace metals between sampling sites and rainwater events might be due the sources of scavenging processes of different air pollutions. The dominant lead sources in precipitation in Tainan Taiwan are sources mixed by gasoline, industrial sources, local sources and long distance transported materials [3].

High concentrations of $\mathrm{Pb}, \mathrm{Cu}, \mathrm{Zn}$, As and $\mathrm{Ni}$ were found in rainwater in Arak City Iran that were emitted mainly from anthropogenic sources (industrial and traffic activities) and soils induced from limestone rocks in mountains and carried out to the city [6].

Trace metals ( $\mathrm{Al}, \mathrm{Fe}, \mathrm{Mn}, \mathrm{Cu}$ and $\mathrm{Zn}$ ) in the precipitation around Okinawa Island Japan were mainly derived from the dissolution of wind-blown soil particles. The distribution of trace metals across the island showed the influence of road traffic as a source and cause of atmospheric pollution [18].

Heavy metal ( $\mathrm{Cu}, \mathrm{Zn}, \mathrm{Cd}$ and $\mathrm{Pb}$ ) in Peng Chia You islet northern Taiwan predominately originate from anthropogenic sources, mostly related to industrial combustion and local traffic emission. The Principal Component Analysis (PCA) results also support this argument, showing that the major heavy metals are derived from local traffic emissions. Concentrations of heavy metals in rainwater are largely derived from long range transport and traffic emission from Taiwan, China and other Asian countries [19].

Atmospheric deposition does contribute to contaminants in rainwater in an urban environment. It shows that there is an increase in the contaminant flux in traffic/industrial areas compared to outer suburbs with marker elements implicating traffic as a major contributor. Rainwater collected in urban areas where air pollution is significant must consider its impacts on the water quality.

Despite the measurable effect of urban activity on contaminant flux, for a subtropical city of nearly 2 
million people the chemical water quality of urban rainwater over annual time periods could still be considered as potable. However, the quality of water collected in a tank may not reflect that of the rainwater, with lead most commonly exceeding drinking water guidelines. This is due to input of contaminants from other sources such as roof materials [20].

It was found that contaminants of rainwater tanks in Melbourne rainwater tanks in Melbourne are commonly contaminated with lead and other heavy metals at levels that exceed drinking water guidelines. It is concluded that metals concentrations and lead concentration particularly, is an important issue which must be addressed in the task of finding alternative water sources for Australian cities [21] and so does in Bandung.

\section{CONCLUSION}

Composition ions and trace metal in rainwater in Bandung has been studied, the rainfall rate ranged between $19.92 \mathrm{~mm}$ to $130.48 \mathrm{~mm}$. The results show that rainwater $\mathrm{pH}$ were 4.10 - 5.95, indicating acidic rainwater.

The dominant chemical composition of rainwater were sulfat $(37 \%-39 \%)$ and ammonium $(17 \%-26 \%)$, followed by nitrate. The trace metals analyses indicated that Lead $(\mathrm{Pb})$ had the highest concentration (mean = $76.68 \mu \mathrm{g} / \mathrm{L})$.

The concentration of the trace metals decreased in order of Fe, $\mathrm{Zn}, \mathrm{Al}, \mathrm{Se}, \mathrm{Cu}, \mathrm{As}, \mathrm{Ba}, \mathrm{Co}, \mathrm{Sr}, \mathrm{Ni}, \mathrm{Cd}, \mathrm{Cr}, \mathrm{Sn}$ and $\mathrm{Sb}$. Lead is a toxic compound, resulting from human activities, such as fossil fuel burning, mining and manufacturing.

The initial analysis of rainwater composition including heavy metas suggested that rainwater contain various and potential harmful substance, including heavy metals in a soluble phase considering the acidic characteristic of the rainwater.

Understanding of trace metal content in precipitation is important to understanding the atmospheric pollution as well as their biogeochemical circle of earth atmosphere.

\section{ACKNOWLEDGEMENT}

This research is partially funded by Riset $K K$ dan Inovasi ITB 2017 as part of the research "Prediksi Dampak Kesehatan Lingkungan Deposisi Basah Logam Berat di Wilayah Perkotaan Bandung”.

\section{REFERENCES}

[1] Begum A., HariKrishna S., Khan I., "Chemical composition of rainwater in South Banglore, Karnataka", Rasayan J. Chem, Vol.1, No.4, pp. 856 - 861. 2008.

[2] Cerqueira M.R.F., Pinto M.F., Derossi I.N., Esteves T.W., Santos M.D. R., Matos M.A.C., Lowinsohn D., Matos R.C., "Chemical characteristics of rainwater at a southeastern site of Brazil", Atmospheric Pollution Research, vol. 5, pp. 253- 261. 2014.

[3] Cheng M.C., You C.F., "Sources of major ions and heavy metals in rainwater associated with typhoon events in southwestern Taiwan", Journal of Geochemical Exploration, vol. 105, pp. 106 - 116. 2010.

[4] Kamani H., Hoseini M., Safari G.H., Jaafari, J., and Mahvi A.H.. "Study of trace elements in wet atmospheric precipitation in Tehran, Iran, Environmental Monitoring Assessment, vol., 186, pp 5059 - 5067. 2014.

[5] Meena M., Meena B.S., Chandrawat U., Rani, A., "Chemical characteristics of rain water at an industrial city of Western India", International Journal of innovative Research in Science, Engineering and Technology, Vol. 3, pp. 14359 - 14367. 2014.

[6] Ghadimi F., Ghomi M., Ranjbar M., Hajati A,’Sources of contamination in rainwater by major and heavy elements in Arak, Iran", Journal of Water Sciences Research, Vol. 5 No. 2, pp. 67 - 84. 2013.

[7] Vijayaraghavan K, Joshi U.M, R. Balasubramanian R., "A field study to evaluate runoff quality from green roofs", Water Research, Vol 46, pp 1337 - 1345. 2012.

[8] Fowler, D., Cape, J.N., Leith, I.D., Choularton, T.W., Gay, M.J dan Jones, A., "The influence of altitude on rainfall composition at Great Dun Fell", Atmosperic Environment, Vol. 22 (7), pp 1355 - 1362. 1988.

[9] Dore, A.J., Choilarton, T.W., Brown R., dan Blackall, R.M., "Orographic rainfall enhancement in the mountains of The Lake District and Snowdonia", Atmospheric Environment, Vol. 26 (3), pp 357 - 371. 1992.

[10] Driejana, Raper, D.W. Gee I.L, "Spatial Variation \& Source Attribution of The Chemical Composition in Acid Deposition in The Peak District, Northern England", Prociding of The $93^{\text {th }}$ Air Waste Management Association Annual Conference \& Exhibition, Salt Lake City, UT. 2000.

[11] Taylor, K., Woowf, C., Ineson, P., Scott, W.A., Rigg, E., Tipping, E., "Variation in Seasonal Precipitation Chemistry with Altitude in The Northeren Pennines, UK", Environmental Pollution, Vol. 104, pp 1 - 9. 1999.

[12] Lee, D.S., Kingdon, R.D., Garland, J.A., Jones, B.M.R., "Parametrisation of the orographic enhancement of precipitation and deposistion in a long-teram, long-range transport model", Annales Geophysicae, Vol. 18, pp 1447 - 1466. Springer Verlag. 2000

[13] Driejana, Lee, D. S., Kingdon R.D., Raper, D.W., dan Gee, I.L., "Modelling acid deposition in the UK at a scale of $5 \mathrm{~km}$ by $5 \mathrm{~km}$ ", Water, Air and Soil Pollution, Vol. 130, pp 319 - 324. 2001.

[14] EANET, "Technical Manual for Wet Deposition Monitoring in East Asia", Scientific Advisory Committee of EANET at its Tenth Session. 2010.

[15] World Meteorogy Organization, "Manual For The GAW Precipitation Chemistry Programme Guilines", Data Quality Objectives and Standard Operating Procedures, GAW Precipitation Chemistry Science Advisory Group, 2015.

[16] Migliavacca D., Teixeira E.C., Wiegand F., Machado A.C.M., SanchezJ., "Atmospheric precipitation and chemical composition of an urban site, Guaiba hydrographic basin, Brazil, Atmospheric Environment, vol. 39, pp. 1829 - 1844. 2005.

[17] Wang H., Han G., "Chemical composition of rainwater and anthropogenic influences in Chengdu, Southwest China, Atmospheric Research, vo. 99, pp. 190 - 196, 2011.

[18] Vuay S.A., Tokuyama A., "Trend of trace metals in precipitation around Okinawa Island, Japan", Atmospheric Research, Vol. 99, pp 80 - 84. 2011. 
[19] Cheng M.C., You C.F., Lin F.J., Huang K.F., Chung C.H., "Sources of $\mathrm{Cu}, \mathrm{Zn}, \mathrm{Cd}$ and $\mathrm{Pb}$ in rainwater at a subtropical islet offshore northern Taiwan", Atmospheric Environment, Vol. 45, pp 1919 - 1928. 2011.

[20] Huston R., Chan Y.C., Gardner T., Shaw G., Chapman H., "Characterisation of atmospheric deposition as a source of contaminants in urban rainwater tanks", Water Research, Vol. 43, pp 1630 - 1640. 2009.
[21] Magyar M.I., Mitchell V.G., Ladson A.R. Diaper C., "Lead and other heavy metals : common contaminants of rainwater tanks in Melbourne", Water Down Under. 2008 